ks. dr Andrzej Turek

KATOLICKI UNIWERSYTET LUBELSKI JANA PAW

\title{
Media w rodzinie - rodzina w mediach. Wzajemne relacje w aspekcie etycznym
}

Zadanie wychowywania nowych pokoleń przypisujemy rodzinie, powołanej do tego ze swej natury. Jednakże - co dziś jest już chyba powszechnie wiadome - również media uczestniczą aktywnie w procesie wychowania, co ważne: tak dzieci, jak i dorosłych. Dla jakości procesu wychowawczego, dla przyszłych pokoleń rodziny ludzkiej relacja rodziny i mediów jawi się więc jako newralgiczna.

\section{Komunikacja aktem moralnym}

Wśród wielu przestrzeni, w których żyją ludzie: rodzinnej, zawodowej, towarzyskiej, coraz większą rolę odgrywa mediosfera, czyli przestrzeń mediów. Funkcjonują w niej wszyscy, nawet ci, którzy twierdza, że są na media odporni, nie czytają gazet i nie mają $\mathrm{w}$ domu telewizora. Funkcjonują w mediosferze choćby przez to, że żyją wśród ludzi, których wiedzę o świecie, przekonania i wartości kształtują w bardzo istotnym stopniu media. Dla ludzi współczesnych, zwłaszcza w rozwiniętych krajach, praktycznie nie ma ucieczki przed mediami.

Każde komunikowanie ze swej natury ma zawsze aspekt etyczny. Przede wszystkim dlatego, że nie dokonuje się ono w moralnej 
próżni. Nie jest etycznie neutralne, ale wywołuje zarówno pozytywne, jak i negatywne skutki, będące efektem zamierzonych poczynań człowieka lub (nie)zamierzonych funkcji bądź dysfunkcji medialnych. „Przestrzeń komunikacji medialnej-trafnie zauważa Michał Drożdż - jest przestrzenią wielorakich ludzkich decyzji, wyborów i działań - dobrych lub złych". Komunikacja jest aktem moralnym, ponieważ rodzi zawsze jakieś konsekwencje, ma wymiar międzyludzki, społeczny i wspólnotowy.

Co istotne, dziś medioznawcy otwarcie przyznaja, że komunikowanie i wychowywanie stanowią nierozłączną całość, albowiem młode pokolenia czerpią wiedzę i życiowe wzorce nie tylko od rodziców, ale też od innych znaczących osób oraz całych przeszłych pokoleń, których dziedzictwo duchowe, w sposób symboliczny, przekazywane jest za pośrednictwem mediów ${ }^{2}$. Każda informacja przez sam fakt, że się pojawia (a przecież mogłaby nie zaistnieć!), jest w istocie formacją lub też deformacją; wychowuje albo deformuje człowieka.

Zazwyczaj zadanie wychowywania nowych pokoleń przypisujemy rodzinie, z natury swojej powołanej do wychowania dzieci³. Rodzina i szkoła to pierwsze miejsca socjalizacji i kulturalizacji młodego człowieka - czyli uczenia go życia w społeczeństwie oraz introdukcji w świat znaczeń kulturowych ${ }^{4}$. Jednakże - co dziś jest chyba już powszechnie wiadome - również media uczestniczą aktywnie w procesie wychowania, tak dzieci, jak i dorosłych. „Aby rozumieć

1 M. Drożdż, Etyczne orientacje w mediosferze, Tarnów 2006, s. 22.

2 Por. T. Goban-Klas, Media i komunikowanie masowe, Warszawa-Kraków 1999, s. 39.

3 Por. Jan Paweł II, Adhortacja apostolska Familiaris consortio, 14.

4 Por. L. Dyczewski, Rodzina. Społeczeństwo. Państwo, Lublin 1994, s. 106-111; por. F. Znaniecki, Socjologia wychowania, Warszawa 2001, s. 102-114. 
skuteczność mediów na polu wychowania - tłumaczy Adam Lepa należy je rozpatrywać w ramach trzech rodzajów funkcji: intencjonalnej (wynikającej z zamiaru nadawcy, tj. komunikatora), funkcji nadanej (obiektywna treść komunikatu, często niezgodna z zamiarem nadawcy) oraz funkcji pełnionej (faktyczny sposób odbioru i reakcji odbiorcy)"s.

Aspekt wychowawczy publikatorów staje się tym wyraźniejszy, gdy uświadomimy sobie, iż to właśnie one współcześnie są największym wytwórcą i dystrybutorem masowej kultury ${ }^{6}$. A kultura zawsze wychowuje przez wartości, z których jest utkana i które promuje. Nie bez powodu Jan Paweł II powiedział wprost, że „pierwszym i zasadniczym zadaniem kultury w ogóle i każdej zarazem kultury jest wychowanie"

Z tej wychowawczej perspektywy zarysowuje się już pierwszy istotny punkt styczności mediów i rodziny. Nabiera ona wyjątkowego znaczenia, gdy skonstatujemy, jak potężną rolę odgrywają publikatory we współczesności.

\section{Zanurzeni w medialnym świecie}

Trudno by nam było wyobrazić sobie życie bez prasy, radia, telewizji, internetu, różnych tzw. nowych mediów. Dzięki mediom jesteśmy

5 A. Lepa, Pedagogika mass mediów, Łódź 2003, s. 46.

6 Por. M. Iłowiecki, Krzywe zwierciadło. O manipulacji w mediach, Lublin 2003, s. 186; por. T. Goban-Klas, Media i komunikowanie masowe, dz. cyt., s. 134.

7 Jan Paweł II, W imię przyszłości kultury, [w:] Wiara i kultura. Dokumenty, przemówienia, homilie, red. M. Radwan, S. Wylężek, T. Gorzkula, Rzym-Lublin 1988, s. 58; por. S. Kowalczyk, Filozofia kultury, Lublin 1997, s. 197-198. 
często niejako naocznymi uczestnikami przestrzennie nawet najbardziej odległych wydarzeń. Na co dzień żyjemy w świecie, w którym ogromne znaczenie mają - będące w powszechnym użyciu - środki masowej komunikacji.

Uczeni stwierdzają jednoznacznie, iż mentalność współczesnych zdominowana jest przez myślenie medialne. Wyraża się to w tym, że ludzie nie tylko myślą tak, jak chcą media, ale też - co istotne (!) głównie o tym, co im podsuwają (przede wszystkim audiowizualne) media, które organizują zbiorową wyobraźnię i ustalają jej granices. Niektórzy mówią wprost, że „żyjemy obecnie w epoce «medialnej religii»" . Jeśli świat, jak powtarza wielu za klasykiem Herbertem M. McLuhanem, stał się (czy staje się) globalną wioską, to dzieje się tak głównie dzięki mediom masowym. Maciej Iłowiecki trafnie konstatuje, iż „globalizacja komunikacji społecznej tworzy nowy rodzaj wspólnoty, nazywany społeczeństwem medialnym (lub-zmedializowanym). Najkrócej znaczy to: społeczeństwo w ogromnej mierze uzależnione od mediów i od dokonywanych przez media interpretacji rzeczywistości, w której żyjemy”10.

Masowe media są liczne, działają systematycznie, ich przekazy są globalnie odbierane - są więc centralnym i konstytutywnym elementem współczesnego świata również przez swój zasięg,

8 Por. K. Klauza, Krajowa Rada Radiofonii i Telewizji jako instytucja nadzorcza, opiniotwórcza i programujaca, [w:] Medialne rozdroże, red. L. Dyczewski, Warszawa 1998, s. 111; por. M. Iłowiecki, Pilnowanie strażników. Etyka dziennikarska $w$ praktyce, Warszawa 2012, s. 168.

9 P. Czarnecki, Etyka mediów, Warszawa 2008, s. 45.

10 M. Iłowiecki, Krzywe zwierciadło, dz. cyt., s. 161-162; por. A. Pratkanis, E. Aronson, Wiek propagandy. Używanie i nadużywanie perswazji na co dzień, przetłum. J. Radzicki, M. Szuster, Warszawa 2003, s. 11-12. 
regularność i powtarzalność. Jan Paweł II, wskazując w liście apostolskim Szybki rozwói ${ }^{11}$, adresowanym do osób odpowiedzialnych za środki społecznej komunikacji, na tę wyjątkową rolę mediów w obecnej dobie, zaznacza przy tym od razu, iż fakt ten powinien generować powszechną troskę o etyczną jakość medialnych treści: „Właśnie dlatego, że środki przekazu oddziałują na sumienie jednostek, kształtują ich mentalność i wpływają na ich wizję rzeczywistości, trzeba jasno i zdecydowanie przypominać, że są one dziedzictwem, które należy chronić i rozwijać. Konieczne jest, aby także sfera przekazu społecznego została włączona w organiczną strukturę praw i obowiązków, zarówno w tym, co dotyczy formacji i odpowiedzialności etycznej, jak i w odniesieniu do praw i działania jako instytucji. Za właściwy rozwój środków przekazu w służbie wspólnego dobra odpowiedzialni są wszyscy i każdy osobiście. Ze względu na ścisłe powiązanie mediów ze sferą gospodarki, polityki i kultury potrzebny jest system zarządzania nimi, zdolny zagwarantować centralne miejsce i godność człowieka, pierwszeństwo rodziny - podstawowej komórki społecznej oraz poprawne relacje między różnymi podmiotami” (SR 10).

\section{Funkcje i władza mediów}

W klasycznym ujęciu mediom masowym przypisuje się trzy zasadnicze funkcje: informowanie, edukowanie (wychowywanie), dostarczanie rozrywki. Choć bywają też medioznawcy, którzy tych

11 Por. Jan Paweł II, List Szybki rozwój [dalej: SR], http://www.opoka. org.pl/biblioteka/W/WP/jan_pawel_ii/listy/szybkir_24022005.html (23.09.2015). 
medialnych funkcji wyliczają więcej: obserwacja otaczającego świata, zapewnienie komunikacji społecznej, tworzenie obrazu rzeczywistości, przekazywanie dziedzictwa kulturowego, nakłanianie do kupowania ${ }^{12}$. Mówi się też o funkcji kontroli społecznej, urabiania opinii, upowszechniania sztuki, integracji i aktywizacji społeczeństwa $^{13}$. Zauważyć wypada, że coraz bardziej dominująca staje się funkcja rozrywkowa mediów. Promieniuje ona wyraźnie na przekaz informacji. Obecnie publikatory chętnie i często serwują odbiorcom swoistą mieszankę/papkę informacyjno-rozrywkową (tzw. infotainment). Rozrywka totalna, przyjmująca często postać kultury bezwstydu, jest niebezpieczna. Neil Postman, amerykański kulturoznawca, pisał: „Bez większego protestu i niezauważenie dla opinii publicznej polityka, religia, informacja, sport, oświata i gospodarka zmieniły się w mediach w dodatek do przemysłu rozrywkowego. Dzięki temu zaczynamy być narodem, który zabawi się na śmierć”14.

W medioznawstwie znana jest teza, wedle której główną - choć nieartykułowaną wprost - funkcją współczesnych mediów masowych jest wpływanie na przekonania, postawy lub zachowania odbiorców w pewnym zamierzonym kierunku. „Oczywiście - dowodzą Piotr Legutko i Dobrosław Rodziewicz - siła i charakter wpływu mediów na ludzkie zachowania i postawy bywa rozmaita i zależy od wielu czynników, jak nakład i poczytność, zasięg nadajników i słuchalność czy oglądalność, rodzaj i stopień wykształcenia odbiorców, ich wiek, płeć, zawód i miejsce zamieszkania, ich orientacja

12 Por. C. J. Bertrand, Deontologia mediów, przeł. T. Szymański, Warszawa 2007, s. 25-27.

13 Por. A. Lepa, Pedagogika mass mediów, dz. cyt., s. 46.

14 Cyt. za: M. Iłowiecki, Krzywe zwierciadto, dz. cyt., s. 186. 
na informację, opinię lub rozrywkę. Oraz to, z ilu i jakich źródeł informacji i opinii dana grupa odbiorców korzysta"15. Z medialnym wpływem łączy się też perswazja publikatorów nakłaniająca odbiorców do permanentnego obcowania $\mathrm{z}$ nimi ${ }^{16}$. Władza medium nad człowiekiem jest specyficzna - potężna, a przy tym w pewnym sensie autokratyczna. Publikatory sprawują władzę, „której obywatele nie są w stanie ani kontrolować, ani odmówić mandatu do jej sprawowania w wyborach"17.

Zasięg władzy mediów obejmuje oczywiście również rodzinę. Podstawowa komórka społeczna odbija też refleksy tak funkcji, jak i dysfunkcji mediów. Jest to o tyle istotniejsze, że - jak wiadomo „przyszłość ludzkości idzie poprzez rodzinę” (FC 86).

\section{Fakt (za)istnienia mediów a życie rodzinne}

Zdaniem Christiny Hardyment, badaczki historii społeczeństw i autorki poradników dla gospodyń domowych, wynalezienie telewizji to jeden z trzech czynników (obok antykoncepcji i pralki), które w największym stopniu wpłynęły na pozycję kobiety w nowożytnej rodzinie, a tym samym na funkcjonowanie całej rodziny. Chodzi tu o wpływ, jaki wynika z samego istnienia medium, które oddziałuje na całokształt życia ludzi (w tym członków rodzin), na ich postawy, system wartości, zachowania, sposób przeżywania czasu ${ }^{18}$.

15 P. Legutko, D. Rodziewicz, Mity czwartej władzy, Warszawa 2010, s. 13; por. A. Lepa, Pedagogika mass mediów, dz. cyt., s. 151-169.

Por. P. Czarnecki, Etyka mediów, dz. cyt., s. 63.

17 P. Legutko, D. Rodziewicz, Mity czwartej władzy, dz. cyt., s. 13.

18 Por. P. Czarnecki, Etyka mediów, dz. cyt., s. 61-62; por. M. Iłowiecki, Krzywe zwierciadto, s. 42-44. 


\section{Telewizor - najważniejszy „domownik”}

W wielu domach odbiornik telewizyjny znajduje się na centralnym miejscu; mówiąc nieco kolokwialnie, jest najważniejszym domownikiem. Telewizor należy do najbardziej aktywnych członków rodziny - towarzyszy w codzienności: przy sprzątaniu, prasowaniu, gotowaniu, jedzeniu - ale też w czasie wyjątkowych rodzinnych wydarzeń (np. odwiedziny świąteczne czy nawet kolędowe). Nie ma chyba żadnej przesady w znanym w świecie medioznawczym stwierdzeniu, że telewizja jest „gumą do żucia dla oczu”.

Obcowanie z mediami pochłania (by nie rzec: pożera) mnóstwo czasu, który każdy członek rodziny mógłby wykorzystać z pożytkiem dla współmałżonka i dzieci, a także dla własnego rozwoju lub jeśli jest osobą wierzącą - dla Boga ${ }^{19}$. Dla zobrazowania problemu przytoczmy parę danych. Statystyczny Amerykanin spędza rocznie około 1,5 tys. godzin przed telewizorem i ogląda blisko 38 tys. filmów reklamowych (z telewizji i magazynów konsumuje do 300 reklam dziennie $)^{20}$. Mózg statystycznego Europejczyka atakuje około 3 tys. reklam dziennie plus tysiące niepotrzebnych wiadomości-śmieci. Dane telemetryczne pokazuja, że systematycznie wydłuża się czas, jaki Polacy poświęcają na oglądanie telewizji. Wedle najnowszych badań w roku 2014 roku statystyczny Polak spędził przed telewizorem średnio 4 godziny, 20 minut i i sekundę dziennie (to o 13 minut

19 Por. Z. Sareło, Media w stużbie osoby. Etyka społecznego komunikowania, Toruń 2002, s. 121.

20 A. Pratkanis, E. Aronson, Wiek propagandy..., dz. cyt., s. 11; por. B. Kwarciak, Co trzeba wiedzieć o reklamie, Kraków 1997, s. 191; D. Doliński, Psychologiczne mechanizmy reklamy, Gdańsk 2003, s. 8. 
więcej niż w roku 2013)21. Wynika z tego, że mieszkaniec Polski oddaje telewizji około 30 godzin tygodniowo, czyli jakieś dobre dwa miesiące życia w roku. Szacuje się, iż ta danina czasu w przypadku najmłodszych widzów jest jeszcze większa. Statystyczne polskie dziecko ogląda telewizję od 4 do nawet 7 godzin dziennie. Te wszystkie dane pozwalają stwierdzić, że jako telewidzowie mamy pierwsze miejsce w Europie ${ }^{22}$. Do tego należy jeszcze dodać czas przed komputerem - niektórzy poświęcają komputerowi i internetowi nawet 10 godzin na dobę.

Warto podkreślić, że cały czas mówimy głównie o skutkach samego zaistnienia mass mediów. W tym kontekście przywołajmy wymowne badanie empiryczne. Otóż w roku 1973 w Kanadzie odkryto sporą osadę, w której ludzi nie znali w ogóle telewizji. Socjologowie zbadali zachowania, postawy, sposób wykorzystywania czasu wolnego w tej społeczności, a potem, kiedy już wkroczyła tam telewizja, po paru latach dokonali badań porównawczych. Okazało się, że: zmalała umiejętność czytania u dzieci i chęć do lektury książek, obniżyła się też ich twórcza aktywność; za to aż o 260 proc. wśród członków miejscowej społeczności wzrosły zachowania aspołeczne, agresywne i przestępcze ${ }^{23}$.

Oczywiście z tych wszystkich przesłanek nie można wyciągać pochopnych wniosków, jakoby media były z gruntu złe. Trzeba

21 Por. Z roku na rok coraz dtużej oglądamy telewizje (raport ogladalności za 2014 rok), http://www.wirtualnemedia.pl/artykul/z-roku-na-rokcoraz-dluzej-ogladamy-telewizje-raport-ogladalnosci-za-2014-rok (07.01.2015).

22 Por. P. Czarnecki, Etyka mediów, dz. cyt., s. 27.

23 Por. M. Iłowiecki, Krzywe zwierciadło, dz. cyt., s. 43; por. P. Czarnecki, Etyka mediów, dz. cyt., s. 99. 
po prostu być świadomym zagrożeń, jakie stwarzają publikatory, aby owocnie z nich korzystać tak w życiu indywidualnym, jak i rodzinnym. Wyzwanie jest tym większe, iż, jak już sygnalizowaliśmy, wielu ludzi żyje dziś pod dyktando mediów i medialnej kultury.

\section{Sacrum i wartości w kulturze medialnej}

Wspomnieliśmy już, iż współcześnie mass media są największym producentem i dystrybutorem kultury zwanej masową, popularną czy medialną. Bodaj najbardziej znaczącą cechą tej kreowanej i rozpowszechnianej przez media kultury jest homogeniczność, czyli w uproszczeniu - ujednolicenie wszystkiego: rzeczywistość skrojona na miarę „standardów tłumu”. Konstatując to, mamy w pamięci słowa Michaela Novaka, amerykańskiego filozofa i politologa, który twierdził, że kultura masowa nie wyraża gustów i potrzeb zwykłych ludzi, tylko je prostytuuje ${ }^{24}$. Faktem jest, iż adresatem medialnej kultury jest odbiorca (konsument) anonimowy, przeciętny, masowy.

Zjawisko to dobrze obrazują chociażby tzw. telenowele czy kanały muzyczne sprofilowane na jedną masową miarę, ignorujące zupełnie różne realia życia odbiorców, ich odmienne środowiska oraz lokalne kultury. Gołym okiem widać dominujący wszędzie (może poza krajami arabskimi) medialny model kultury anglosaskiej, zwłaszcza w jej niewyszukanej edycji popamerykańskiej ${ }^{25}$. Rdzeniem i kośćcem każdej kultury są wartości - mówi się wprost, iż kultura jest kultem

24 Por. M. Novak, Przebudzenie etnicznej Ameryki, przeł. H. Pawlikowska, Warszawa 1985, s. 226.

25 Por. P. Czarnecki, Etyka mediów, dz. cyt., s. 98-99. 
wartości ${ }^{26}$. Przyjmowane i promowane przez medialną kulturę wartości można - w pewnym uproszczeniu - podzielić na trzy grupy:

- hedonistyczne: zabawa, wygoda, konsumpcja z reguły łącząca się z przyjemnością;

- witalne: zdrowie, uroda, kult ciała i „wieczystej” młodości;

- ekonomiczne: pieniądze, praca, konto (zasobne), standard życia (wysoki), sukces - szybki, spektakularny i niewątpliwy ${ }^{27}$.

Skoro, jak stwierdziliśmy za Janem Pawłem II, papieżem rodziny, pierwszym zadaniem kultury jest wychowanie człowieka, rodzi się bardzo zasadne pytanie: jakiego człowieka wychowa (wychowuje) kultura medialna, której kościec stanowi kult przyjemności, ciała i pieniądza?

Co równie istotne z punktu widzenia życia rodziny i jej funkcji wychowawczych, medialna kultura, głównie z motywów komercyjnych, dokonuje ekspansji w sferę sacrum. Jest prawie regułą, że w wyniku medialnej obróbki chrześcijańskie sacrum zyskuje jakościowo nową tożsamość - świeckie oblicze. Choć forma symbolu jest religijna, to już treść zupełnie świecka. Dość tutaj przywołać przykład św. Mikołaja, biskupa, który w medialnej popkulturze bywa skąpo ubraną hostessą czy nawet jakimś zwierzęciem; walentynek - święta dowodzącego, jak olbrzymią siłę oddziaływania mają media, które potrafiły w Polsce „wyczarować” Dzień Zakochanych właściwie nagle i od zera-znamienna rzecz, iź św. Walenty, męczennik, w stylistyce medialnego przekazu stał się pucołowatym amorkiem, bożkiem

26 Por. A. Tyszka, Kultura jest kultem wartości. Aksjologia spoteczna - studia i szkice, Lublin 1993, s. 7n.

27 Por. A. Sugier-Szerega, Wartości kultury popularnej w mediach, [w:] Kultura w kręu wartości, red. L. Dyczewski, Lublin 2001, s. 158-161. 
miłości. Wspomnijmy jeszcze o Arielu. Biblijnie to „ołtarz Boży”, „ognisko Boże” „Lew Boży” - symboliczna nazwa, jaką prorok Izajasz nadaje Jerozolimie (por. Iz 29, In). Ale chyba każdy kojarzy tę nazwę tylko z proszkiem do prania, bo jako taka została upowszechniona $w$ medialnych przekazach. Wielu ludzi, przy swej ignorancji w sprawach wiary, postrzega religię przez pryzmat wykrzywionego sacrum - takiego, jakie widzą w reklamie i (lub) medialnej kulturze. Świętość odcina się od swych korzeni i zaczyna żyć własnym medialnym życiem ${ }^{28}$. Podobne zjawisko dotyczy również Kościoła katolickiego, którego medialny obraz jest z reguły daleki od rzeczywiści, wykoślawiony, pełen krzywdzących stereotypów ${ }^{29}$. Z tej perspektywy wydaje się zasadne dodanie, że media masowe pełnią wiodącą rolę w procesie desakralizacji świadomości i mentalności współczesnych ludzi ${ }^{30}$.

Jako że rodzina jest „Kościołem domowym”, pierwszym miejscem przekazu wiary i religijnego wychowania (por. KKK 1666) ${ }^{31}$, powyższe fakty niosą dla współczesnych rodzin bardzo poważne wyzwania w ich misji wychowawczo-ewangelizacyjnej.

28 Por. A. Turek, Sacrum na sprzedaż. Symbolika chrześcijańska w reklamie, Lublin 2002.

29 Por. Kościót. Stereotypy, uprzedzenia, manipulacje, red. M. Przeciszewski, Warszawa-Lublin 2012; por. M. Iłowiecki, Krzywe zwierciadło, dz. cyt., s. 207-223; A. Lepa. Mity i obrazy, Łódź 1999, s. 23-24; J. Nagórny, Religia i religijność w telewizji, [w:] O Рапи Bogu w telewizji, red. L. Dyczewski, Częstochowa 1996, s. 63-80.

30 W. Skrodzki, Media a desakralizacja sztuki, [w:] Religia a mass media, red. W. Zdaniewicz, Warszawa-Ząbki 1997, s. 92.

31 Por. Katechizm Kościoła Katolickiego [dalej: KKK], Poznań 1994; por. M. Braun-Gałkowska, Psychologia domowa, Olsztyn 1990, s. 97-105. 


\section{Przekazy medialne a życie odbiorców}

Nadawcy często tłumaczą (się), że media są po prostu takie, jakie chcą mieć odbiorcy. To w dużej mierze manipulacja i demagogia. Prawda wygląda bowiem inaczej: to media kształtują i wychowują sobie odbiorców. Z punktu widzenia etyki chrześcijańskiej nadrzędnym celem istnienia mediów powinien być wzrost wspólnotowości rodziny ludzkiej i wszechstronny rozwój człowieka (ludzi) - czyli, jak to ujęła sygnowana przez Pawła VI instrukcja pastoralna o środkach społecznego przekazu Communio et progressio, „zjednoczenie i postęp społeczności ludzkiej”32. Ale publikatory mają własne cele; są przecież także przedsiębiorstwami, a przedsiębiorstwo istnieje po to, by zarabiać pieniądze. Oczywiście samo w sobie nie jest to niczym złym ani niewłaściwym. Problem pojawia się wtedy, gdy media - firmy traktują odbiorców instrumentalnie: chcą ich pozyskać jak najwięcej, po to, by jak najdrożej sprzedać reklamodawcom. Odbiorców pozyskuje się głównie poprzez eksploatowanie najniższych ludzkich instynktów, epatowanie tanią sensacją, szokującym obrazem, a nie merytoryczną treścią (tzw. tabloidyzacja). Wśród tego typu zabiegów szczególnie dwa zdają się mieć istotne znaczenie dla życia rodziny: medialna przemoc i erotyzacja.

32 Por. Communio et progressio, I [w:] Kościół ośrodkach komunikowania myśli, red. J. Góral, K. Klauza, Częstochowa 1997, s. 174-274, por. K. Pokorna-Ignatowicz. Kościół w świecie mediów. Historia, dokumenty, dylematy, Kraków 2002, s. 143. 


\section{Przemoc i agresja}

To chyba najczęściej i najszerzej analizowany efekt funkcjonowania mediów. Sprowadza się on w istocie do pytania, czy przemoc i agresja w mediach (chodzi głównie o telewizję, ze względu na jej zasięg i możliwości oddziaływania) prowadzą do wywołania bądź nasilenia agresji i zachowań aspołecznych u odbiorców; a jeśli tak, to u jakich odbiorców? Wielu badaczy wypowiada się różnie. Największy konsensus zdaje się panować odnośnie do odbiorców najmłodszych. Przeważająca większość znawców problematyki uważa, że przemoc ekranowa generuje przemoc realną - dotyczy to zwłaszcza dzieci.

W przestrzeni medialnej mamy teraz spore nasycenie przemocą bajek i gier komputerowych. Obraz, ruch, gest niezwykle sugestywnie oddziałują na młodego odbiorcę, instruując go, angażując emocjonalnie i, z reguły jak to u dzieci, wzbudzając chęć naśladownictwa ${ }^{33}$. Dzieje się tak zwłaszcza wtedy, gdy przemoc ukazywana jest jako atrakcyjna, bezkarna, mająca aplauz grupy rówieśniczej, a bohater odwołujący się do niej jest „pozytywnym” charakterem działającym w imię „szlachetnej” pobudki (np. wymierzając karę za czyjąś krzywdę).

Według danych Instytutu Badań Edukacyjnych aż 10 proc. polskich uczniów pada ofiarą dręczenia w placówkach edukacyjnych. Zjawisko agresji eskaluje zwłaszcza w klasach od IV do VI szkoły podstawowej, ofiarami padają dzieci z rodzin ubogich, nieradzące sobie na WF-ie, wyróżniające się na tle rówieśników i pozbawione

33 Por. M. Braun-Gałkowska, I. Ulfik-Jaworska, Zabawa w zabijanie. Oddziaływanie przemocy prezentowanej $w$ mediach na psychikę dzieci, Lublin 2002. 
wsparcia rodziców - w 60 proc. uczniów podstawówki i gimnazjum istnieje zjawisko tzw. odrzuconych ${ }^{34}$. Bez wątpienia jednym $\mathrm{z}$ istotnych źródeł szerzenia się przemocy w szkole są obrazy przemocy oglądane, czy raczej przeżywane w mediach.

Co ważne z punktu widzenia życia i funkcji rodziny, negatywne oddziaływanie scen przemocy zmniejsza się, gdy dzieci oglądają je wraz z rodzicami, którzy tłumaczą im nie tylko mechanizmy zła, ale przede wszystkim aspekty moralne, jakie ono generuje $e^{35}$. Warto przy tym wspomnieć, iż oglądanie przemocy w każdym wieku wpływa na obniżenie progu wrażliwości człowieka; bywa, że owocuje to szukaniem coraz mocniejszych podniet, grozi uzależnieniem i potencjalnie przestępczymi zachowaniami.

\section{Erotyka i pornografia}

Samo określenie tego, co jest pornografią, a co erotyką czy kreacją artystyczną, stanowi poważny, wręcz stały i nierozwiązywalny problem. Definicje w tym względzie podyktowane są nie tylko wrażliwością ich autorów, ale przede wszystkim systemem wyznawanych przez nich wartości, a niekiedy niestety również tym, kto finansuje opinię danego biegłego.

Bezsprzecznym faktem jest, że współcześnie mamy ogromne nasycenie medialnych przekazów erotyką, nierzadko w połączeniu z przemocą i agresją. Stosowne badania nie dają tu, jak dotąd, jednoznacznej odpowiedzi na pytanie o rzeczywisty zakres i znaczenie

34 Por. http://wpolityce.pl/spoleczenstwo/266282-polskie-szkolynieprzyjazne-dzieciom-co-dziesiaty-uczen-jest-dreczony (29.09.2015).

35 Por. M. Iłowiecki, Krzywe zwierciadto, dz. cyt., s. 40, 109-111. 
wpływu medialnej erotyki na zachowania ludzi. Większość ekspertów skłania się jednak do stwierdzenia, iż „medialna seksualność”, zwłaszcza w swym zwulgaryzowanym wydaniu, ogromnie spłyca kulturę ludzkich uczuć i prowadzi do permisywizmu, czyli kierowania się wyłącznie przyjemnością, bez żadnych odniesień do odpowiedzialności. Psychologia twierdzi, że obrazy naznaczone dużą dawką mocnej erotyki czy tym bardziej pornografii mają niezwykłą trwałość - ogromnie poruszają zwłaszcza młodych odbiorców i są praktycznie nieusuwalne z mózgu ludzkiego. Warto może jeszcze zauważyć, iż medialny kult ciała nie ma wiele wspólnego z chrześcijańską wizją ludzkiej płciowości; deformuje u młodzieży postrzeganie daru cielesności i jej znaczenia w relacjach międzyludzkich.

Zalew erotyki, a szczególnie pornografii, jest niebezpieczny także dla dorosłych. Narusza, wręcz niszczy u odbiorców poczucie odpowiedzialności, intymność, szeroko pojętą kulturę uczuć; bywa, że uzależnia i generuje zachowania dewiacyjne ${ }^{36}$. Słychać niekiedy głosy, iż obecna w mediach erotyka może mieć dla małżonków wymiar edukacyjny. Okazuje się jednak, iż stosowanie w intymnym pożyciu zasady „Co na ekranie - to na tapczanie” rodzi wiele problemów małżeńskich, a w skrajnych przypadkach prowadzi nawet do rozkładu związku.

\section{Telerodzinka.pl}

Papieskie Orędzie na Światowy Dzień Środków Społecznego Przekazu w 2015 roku zostało poświęcone relacji rodziny i mediów. Papież

36 Por. M. Iłowiecki, Krzywe zwierciadto, dz. cyt., s. 39-40. 
Franciszek - wskazując, że rodzina jest pierwszym i podstawowym miejscem, gdzie uczymy się komunikowania - napisał między innymi: „Media niekiedy mają tendencję do takiego przedstawiania rodziny, jakby to był abstrakcyjny model do przyjęcia lub odrzucenia, do obrony lub atakowania, a nie konkretna rzeczywistość, w której się żyje; albo jakby była czyjąś ideologią przeciwko ideologii kogoś innego, a nie miejscem, w którym wszyscy uczymy się, co to znaczy porozumiewać się w miłości otrzymywanej i dawanej”37.

Obraz rodziny w mediach opalizuje skrajnościami. Seriale i telenowele pozwalają tutaj zauważyć wyraźną dwubiegunowość. $\mathrm{Z}$ jednej strony mamy więc Klan (nomen omen) - a nim rodzinę rozbudowana, ,autentyczną”, wielopokoleniową, a z drugiej niepełną w wielu konotacjach i znaczeniach tego słowa, a więc: małżonków bezdzietnych, matki czy ojców samotnie wychowujących dzieci czy wreszcie rodziny życiowo dowcipne (Rodzinka.pl), skąpane w konwencji sitcomowego żartu (Miodowe lata) albo wyraźnie tragikomiczne, ocierające się o patologiczną groteskę (Świat według Kiepskich). Medialna poetyka rodziny współkreowana jest w dużej mierze przez koncepcje społecznych ról kobiety. To - zwłaszcza w magazynach dla pań - bizneswoman, gwiazda, pachnący markowymi perfumami obiekt pożądania, wyzwolona i niezależna singielka, ale też tradycyjnie zaradna gospodyni domowa, przykładna żona i matka.

Samo macierzyństwo również jest prezentowane dwubiegunowo: od ciężaru, problemu po radość spełnionych oczekiwań. Scenarzyści, oprócz już poniekąd standardowego zarabiania na lokowaniu

37 Por. Franciszek, Przekaz o rodzinie jako uprzywilejowanym miejscu spotkania $w$ bezinteresownej mitości, http://www.opoka.org.pl/biblioteka/W/WP/ franciszek_i/przemowienia/massmedia_23012015.html\# (20.09.2015). 
produktu (średnio, w zależności od stacji i programu, przynosi to dochód od 30 do 95 tys. zł za odcinek - w TVP 65 tys. zł ${ }^{38}$ - zdają się niekiedy wchodzić na teren sporów ideologicznych, poruszając kwestie in vitro, homoseksualizmu czy tzw. homofobii. Dzieci pełnią rolę reklamowych wabików, szczególnie w przypadku reklam słodyczy, zabawek, farmaceutyków i różnorakich gadżetów kultury popularnej towarzyszących produkcjom adresowanym do tego segmentu rynkowego (bajki, kreskówki, gry). W medialnym obrazie rodziny między jej członkami obowiązują prawa partnerstwa, dość chętnie eksponowany i eksplorowany jest przy tym motyw konfliktu pokoleń. Na porządku dziennym jest więc „wojna domowa” - by posłużyć się tytułem swego czasu popularnego serialu - między nastoletnimi pociechami nastawionymi na luz i totalną zabawę a ich rodzicami pacyfikującymi dorastające latorośle ${ }^{39}$.

\section{Miraż medialnych zażyłości}

Zważywszy na siłę oddziaływania mediów - zwłaszcza telewizji można rzec, iż telenowele czy programy familijne zawierające pewien model rodziny i ukazujące styl jego realizacji, dla wielu odbiorców stają się wzorcami do naśladowania. Kolorowy medialny świat często wypiera realny z jego nieuchronną szarością i życiowymi problemami. Sprawia, że relacje rodzinne korodują bądź stają się powierzchowne. Zdarza się, i to nierzadko, iż członkowie

38 Por. http://www.wirtualnemedia.pl/artykul/w-tvp-lokowanieproduktow-najdrozsze-w-m-jak-milosc-i-ranczu-w-tvn-u-kubywojewodzkiego-a-w-polsacie-w-top-chefie (20.09.2015).

39 Por. A. Sugier-Szerega, Wartości kultury popularnej w mediach, dz. cyt., s. 160. 
rodzin utożsamiają się z postaciami bohaterów filmów, podziwiają celebrytów, znanych z tego, że są znani, emocjonują się ich życiem bardziej niż życiem swych bliskich; żyją w rytm życia telenowel, choć te nie mają wiele wspólnego z ich sprawami. „Odbiorca traktuje telewizyjnych bohaterów jak herosów - dowodzi Paweł Czarnecki których naśladuje w sposobie bycia, mówienia, wreszcie myślenia i wartościowania"40.

Bezrefleksyjni konsumenci obrazów stają się również bardziej podatni na manipulacje $e^{41}$. Trudno nie zgodzić się z publicystą Wojciechem Wenclem, który w jednym ze swoich felietonów wskazuje, iż bezkrytyczne karmienie się przez ludzi medialną iluzją pozwala sternikom świadomości dowolnie eksplorować także pokłady pozytywnych uczuć i szlachetnych odruchów serca - ze szkodą dla zdrowego rozsądku, fundamentalnych wartości i dobra tradycyjnie pojętej rodziny. „Serce oderwane od realnych doświadczeń zostaje następnie sformatowane przez media - pisze Wencel. - [...] Po tym praniu serc i mózgów odbiorcy mediów są już przygotowani na wzruszanie się losem homoseksualistów i transwestytów, nie wspominając o przestępcach aresztowanych przez CBA o szóstej rano. Gdy oglądają na ekranie posłankę, która zgodziła się na korupcję, widzą jedynie rzęsiste łzy «oszukanej» kobiety. Logika i wartości nie mają już dla nich znaczenia. Błąkając się w labiryncie medialnej iluzji, chcą po prostu poczuć się dobrymi ludźmi. Ich plastelinowe serca mogą być dowolnie kształtowane przez siewców chaosu”42.

40 Por. P. Czarnecki, Etyka mediów, dz. cyt., s. 62.

41 Por. A. Lepa, Pedagogika mass mediów, dz. cyt., s. 181n; por. A. Lepa, Mity i obrazy, dz. cyt., s. 27-47.

42 W. Wencel, Serce z plasteliny, „Gość Niedzielny” (2015) nr 15, s. 74. 
Publikatory stwarzają wrażenie uczestniczenia we wspólnocie, a w rzeczywistości oddalają ludzi od siebie, zastępując relacje interpersonalne ułudą medialnych zażyłości. Dzieje się tak ze szkodą dla rodziny, będącej - jak czytamy w papieskim orędziu z 2015 roku - „pierwszym miejscem, w którym uczymy się porozumiewać” i „wzorem wszelkiego przekazu”. Okazuje się jednak, iż rzeczywistość wirtualna może nie tylko górować nad realną, ale też ją deprecjonować. Życie rodzinne, przebywanie z kimś 24 godziny na dobę wymaga cierpliwości, dialogu, kompromisów - słowem: ofiarnej miłości. Codzienność obowiązków i ról rodzinnych z natury rzeczy bywa szara i męcząca. A z drugiej strony ekran czy monitor ukazuje nam intrygujący, wielki kolorowy świat niekończącej się rozrywkowej feerii. Żona, która może przytyła po ciąży, prezentuje się mniej ponętnie niż jakaś pięciominutowa gwiazdka obrobiona w Photoshopie i zawieszona na medialnym firmamencie show biznesu; mąż, któremu po czterdziestce ubyło włosów na głowie, a przybyło ciała na brzuchu, to nie celebryta: ciacho z "kaloryferem” na brzuchu...

\section{Sielski żywot singla poczciwego}

Najogólniej rzecz ujmując, współczesny świat mainstreamowych mediów nie patrzy życzliwie na tradycyjnie pojęte małżeństwo i rodzinę. Żyjemy w kulturze nieprzychylnej sakramentalnemu małżeństwu, dyskryminującej rodzinę. Pojawia się coraz więcej filmów czy seriali, w których rotacja partnersko-łóżkowa jest tak szybka, że czasem nawet $\mathrm{w}$ danym odcinku nie bardzo wiadomo, kto z kim śpi. Polityczna poprawność praktycznie wyeliminowała z języka mediów słowo „małżonek (mąż, żona)”, zastąpiono je słowem wytrychem: 
„partner”, importowanym z branży handlowo-usługowej, które może znaczyć wszystko i nic.

Zauważalny jest przy tym silny dyktat kultury singli. W dawnym określeniu mówiło się „stara panna” czy „stary kawaler” i nie było w tym nic specjalnie pochlebnego czy tym bardziej nobilitującego. Co innego być singlem... W mediach przed odbiorcą roztacza się kuszącą wizję żywota singla szczęśliwego. Panie (np. z serialu Seks $w$ wielkim mieście) nie rodzą, więc na sądzie ostatecznym stawią się z brzuchem płaskim jak niemieckie autostrady, dyplomami kilku fakultetów, CV, które ledwo pomieszczą mnogość ich przeżyć, kompetencji, doświadczeń. Panie z serialu Przyjaciótki właściwie nieustannie miotają się między samotnością a toksycznymi damsko-męskimi relacjami, a czynią to ze świadomością, że mogą liczyć tylko na siebie nawzajem.

Są też oczywiście single - panowie. Tutaj zauważyć można znów grę skrajności: od szarych „zdezelowanych” życiem kawalerów bez perspektyw (serial Chtopaki do wzięcia) przez medialną "quasi-singlo-poligamię" wiecznego Piotrusia Pana (serial 39 i pót) po ludycznych przystojniaków nakrapianych Diorem, efebów kariery z nielimitowaną dyspozycyjnością, którzy życie traktują jak jedną niekończącą się imprezę (np. postać Marcina Kaszuby z serialu O mnie się nie martw). W tle pulsuje zwykle finansowy i życiowy komfort: totalna w ol n o ść - można jechać na urlop, gdzie się chce, bez dziecka - żywego bagażu; można żyć pełnią życia bez pieluch, niespania po nocach, kiedy dziecku idą zęby albo kiedy nastolatkowi nie bardzo idzie życie.

Wracając na ziemski padół z planety singli: niby wszystko wydaje się wspaniałe. Tylko nie wiadomo dlaczego wielu takich singli, szczęśliwych na ekranie, patrzących z politowaniem i wyższością 
na rodzinne pielesze - na kury domowe, kapciowych tatusiów i umorusane dzieciaki - odbiera sobie życie. W okresie Bożego Narodzenia, zwłaszcza podczas Wigilii, notuje się zastraszająco częste samobójstwa „jedynaków życia”.

\section{Familijne reality show}

W publikatorach, zwłaszcza komercyjnych, roi się od programów typu reality show oraz fabularyzowanych dokumentów. Wprost lub pośrednio jest $\mathrm{w}$ nich obecna również problematyka małżeńsko-rodzinna. Oczywiście przedstawiona na swój sposób, czyli w sensacyjno-skandalizującej konwencji. Można tu wymienić takie paradokumenty - kalki anglojęzycznych pierwowzorów - jak: Surowi rodzice, Dlaczego ja?, Trudne sprawy, Pamiętniki z wakacji. W tej ostatniej produkcji pokazuje się głównie problemy młodych na wakacjach w jakiś egzotycznym kraju; perypetie dość niewyszukane w swej tematyce, bo ogniskujące się wokół romansowania i imprezowania, tego, kto z kim, pod kim, nad kim, o kim itp. Zdarzają się tematy „ambitniejsze” - jeden odcinek opowiadał o tym, że pewien pan tata, będąc na urlopie, pomylił $\mathrm{w}$ hotelowej łazience klozet $\mathrm{z}$ bidetem, bo tego ostatniego "nie widział nigdy, nawet w TV”.

Niejako dopełnieniem tego typu produkcji jest fabularyzowany dokument Słonce, woda, totalna swoboda. Pokazuje on to samo, co Pamiętniki z wakacji, tzn. upijanie się, podrywanie i wygłupianie, $\mathrm{z}$ tą modyfikacją, iż zarejestrowane kamerą wakacyjne wyczyny nastolatków oglądają potem ich rodzice. Zresztą nie namęczą się w tej roli, ich reakcje są do bólu schematyczne: patrzą, kiwają głowami i co jakiś czas wzdychają: „Oh my God!”. À propos życia małżeńskiego, wspomnijmy jeszcze paradokument Zamieńmy sie 
żonami. W programie występują dwie rodziny, różniące się od siebie diametralnie stylem życia, nawykami, zwyczajami etc. W czasie dwutygodniowego wyjazdu dokonuje się małżeński miks: zamiana współmałżonków, którzy zapoznają się z życiem tej drugiej rodziny. $\mathrm{Na}$ koniec ma miejsce powrót do prawowitego stadła i wymiana doświadczeń.

Jako komentarz do tego typu małżeńsko-rodzinnych ekspresji medialnych przytoczmy słowa Wojciecha Wencla, który recenzując program Zamieńmy się żonami, pisał: „Dezyderata na miarę XXI wieku: zamieńmy się żonami, dziećmi i domami. Rozwijajmy osobowość, wydzierajmy się, rozwódźmy się. Zmieniajmy powołanie, płeć, maski na twarzy. Orientujmy się seksualnie. Wyjeżdżajmy, odchudzajmy się, uczmy się stu języków, próbujmy wszystkiego. Medytujmy. Chichoczmy, biegnijmy, bogaćmy się, dziergajmy sobie tatuaże na lędźwiach. W innych historiach, ciałach, rodzinach, kulturach i religiach na pewno będziemy szczęśliwsi. Zamieńmy się głowami. Z orangutanami”43.

\section{Widz - podglądacz i sędzia}

Różne talkshow zajmujące się problematyka, nazwijmy to, pararodzinną, czy może lepiej paramałżeńską (partnerską), tworzone są w podobnej sensacyjno-tabloidowej poetyce. Na przykład większość programów Ewy Drzyzgi Rozmowy w toku czy amerykańskich Jerry Springer Show, kręci się wokół przysłowiowej części ciała pani Maryni. Nierzadko w tego typu produkcjach widz - poprzez różne konkursy,

43 W. Wencel, „Gość Niedzielny” (2011) nr 49, dodatek telewizyjny, s. 13. 
sondy SMS - staje się nie tylko podglądaczem „sensacji”, ale też sędzią w dylematach moralnych. Tym samym medium czyni z niego eksperta w etyce. Telewidz-ekspert rozstrzyga, co jest dobre, a co złe; co właściwe, a co naganne; czy małżonkowie (partnerzy) powinni się rozstać, czy jednak nadal być ze sobą. I czyni to, w żadnym stopniu nie odpowiadając za artykułowane sądy. „Telewizor - konstatuje Kapuściński - zapewnia nowy typ uczestnictwa - uczestnictwa bez odpowiedzialności. Dawniej było to niemożliwe: być, uczestniczyć w czymś, to znaczyło także - jeżeli zaszła potrzeba - współodpowiadać"44.

Tym sposobem prawda, dobro, zło, piękno, wierność, miłość stają się względne, a o adekwatności zasad i wyborów moralnych decyduje zwyczajna arytmetyka. Widz aktywnie uczestniczy w konstruowaniu etyki sytuacyjnej w oparciu o własne widzimisię, bezwiednie słuchając przy tym podszeptów dyżurnych pseudoautorytetów i całej zlaicyzowanej kultury, w której zanurzonych jest większość mediów.

W tym wszystkim obowiązuje zasada totalnego ekshibicjonizmu. Nie ma małżeńsko-rodzinnej sfery, której by się nie dało - poprzez media - wystawić na widok publiczny, sprzedać na medialno-komercjalnym targowisku bezwstydu. Dzieje się dokładnie tak, jak w słynnej swego czasu piosence:

Wow! Talk show

ktoś przed kamerą spodnie zdjął

powiedział, ile razy może

i z kim od wczoraj dzieli łoże

Europejczyk, a nie jakiś koł.

Wow! Talk show.

44 R. Kapuściński, Lapidarium III, Warszawa 1997, s. 39. 


\section{Uformować nową „rodzinę"?}

Warto pamiętać, że zdecydowana większość mediów masowych w Polsce należy do obcego kapitału. Zagranicznym właścicielom polskojęzycznych mediów nie musi zależeć na dobru i rozwoju polskiej rodziny. Do tego ludzie w mainstreamowych mediach, których siła oddziaływania (rażenia) jest największa, w większości dalecy są od światopoglądu chrześcijańskiego, a zwłaszcza etyki katolickiej. A przecież to oni konstruują o k n o, poprzez które oglądają (perceptują) świat także katolicy. Jeśli, jak już wspominaliśmy, mass media kształtują gusta i upodobania odbiorców, to czynią tak również odnośnie do rodziny.

\section{Homo lepszy i romanSIDŁA}

Coraz mocniej, także przez publicznych nadawców, promowany jest homoseksualizm. W sierpniu 2015 roku telewizja wyemitowała etiudę filmową Pocatunek (prod. polska 2013, reż. Filip Gieldon), czyli, jak głosi opis: pełną „dramatyzmu i romantyzmu opowieść o pierwszym spotkaniu dwóch kobiet. Każda minuta tej znajomości wprowadza je w nieznane terytoria uczuć i namiętności”. Co warte podkreślenia, film o dwóch lesbijkach: 20-letniej Emilii i 32-letniej Matyldzie został dofinansowany przez Polski Instytut Sztuki Filmowej. Program Drugi TVP we wrześniu 2015 roku pokazał kolejny „kontrowersyjny” obraz kina LGBT (ang. lesbian, gay, bisexual, transgender) - Płynqce wieżowce (prod. polska 2013, reż. Tomasz Wasilewski) epatujący widzów „odważnymi scenami gejowskiego seksu”.

$\mathrm{W}$ tzw. głównonurtowych mediach relacje z "parad równości”, będących $w$ istocie obrazą moralności publicznej i gorszących 
krzewieniem dewiacji seksualnych, są bardzo jednostronne: zwykle pokazują racje tylko jednej strony. Lobby progejowskie wmawia ludziom, że homoseksualista jest z definicji lepszy od hetero, a już zwłaszcza od heterokatolika - z reguły antypatycznego homofoba... W 2008 roku laureatami Róż Gali w kategorii „Piękne Pary” (w plebiscycie organizowanym przez tygodnik „Gala”) zostali Tomasz Raczek i jego życiowy partner Marcin Szczygielski. Uroczystość nagrodzenia „najpiękniejszej pary roku” transmitowała polska telewizja publiczna (TVP2), finansowana głównie przez katolików i mająca ustawowy obowiązek służyć umacnianiu rodziny oraz kierować się w swej misji wartościami chrześcijańskimi ${ }^{45}$.

Różnej maści portale internetowe czy ilustrowane magazyny, zwłaszcza dla kobiet, uczą je, jaką powinna być współczesna modna i postępowa pani, jak powinna ustawiać swe relacje z partnerem, jak wychowywać dzieci i spędzać czas wolny. Zdarza się, że takie porady czy sugestie zawierają wskazówki godzące w sakramentalne małżeństwo, zwłaszcza w kwestii wierności. W czasopiśmie „Wprost”, pretendującym do miana tygodnika opinii, we wrześniu 2012 roku ukazał się artykuł $Z$ drada nasza powszednia ${ }^{46}$, a w nim teza, iż co trzeci Polak (Polka) zdradza swego partnera; ba, romanse i „skoki na boki” często czynione są za przyzwoleniem tej drugiej „postępowej” połówki, która w ten sposób chce sprawić partnerowi przyjemność i urozmaicić jego życie erotyczne. Filozofia powszechnej i wręcz „naturalnej” niewierności to również oś konstrukcyjna

45 Por. Ustawa z dnia 29 grudnia 1992 r. o radiofonii i telewizji, Dz.U. 1993 nr 7 poz. 34, art. 4 p. 1 ; ; art. 18 p. 2; art. 21 p. 6-7.

46 Por. A. Jankowska, B. Janiszewski. Zdrada nasza powszednia, „Wprost” (2012) nr 35, s. 93. 
i praktyczne przesłanie popularnego paradokumentu $Z d r a d y$ emitowanego w jednej z telewizji komercyjnej. Czy więc można się dziwić, że pewien portal randkowy reklamował się hasłem: „Życie jest krótkie. Zafunduj sobie romans".

Spróbujmy może od razu zafundować sobie krótki bilans „dobrodziejstw" romansów i skoków na boki. Z jednej strony mamy: naskórkową przyjemność, ulotną ekscytację, chwilowe novum w powszedniości o smaku zakazanego owocu. A z drugiej strony: wykańczające system nerwowy nieustanne kombinowanie podwójnego życia, realną ofiarę w osobie zdradzonego współmałżonka, złamaną przysięgę, potencjalną chorobę weneryczną, a dla wierzących ciężki grzech grożący utratą zbawienia. Doprawdy: życie jest zbyt krótkie i zbyt piękne, by fundować sobie romanSIDŁA, zamiast inwestować w trwały związek małżeństwa i rodziny...

\section{Reklama a rodzina}

Wraz z rozwojem mediów masowych zaczął się rozkwit reklamy. Reklama z założenia ma pełnić rolę powiadamiania o towarze bądź usłudze, z tym że to powiadamianie jest w reklamie zawsze nakłanianiem. Dlatego zdaniem wielu samo istnienie reklamy jest już problemem etycznym. Reklamę wynaleziono po to, aby przynosiła i pomnażała zysk. Bardzo często nie mówi ona prawdy czy całej prawdy; manipuluje, generuje sztuczne potrzeby i nakłania do ich zaspokajania. Z tej perspektywy widać wyraźnie, że obecna w mediach reklama może stanowić poważny problem dla rodzin. 


\section{Upiory konsumpcji nad pustą miską}

Poprzez agresywną reklamę propaguje się także wzorce konsumpcyjnego stylu życia. Rozbudzanie konsumpcji odbija się zawsze negatywnie na kondycji duchowej społeczeństwa, komercjalizuje mentalność i relacje międzyludzkie, podstępnie ogołaca budżety, zwłaszcza ubogich ludzi. Rodzi też frustrację u młodych, którzy widzą atrakcyjny towar $\mathrm{w}$ zasięgu ręki, a nie mają środków ani perspektyw, by go mieć. Zdarza się więc, że reklama prowokuje pośrednio zachowania przestępcze: kradzieże czy rozboje. Raz jeszcze warto podkreślić, że szkodliwość reklamy jest tym większa, im uboższe społeczeństwo, do którego jest ona kierowana. Instrukcja pastoralna Communio et progressio uczy wyraźnie, że w przypadku krajów będących na dorobku „szkodę wywołuje taka reklama, która cały postęp sprowadza do zaspokajania sztucznie stworzonych potrzeb i skłania do trwonienia na nie większej części posiadanych zasobów, ze szkodą dla rzeczywistych potrzeb i wymagań autentycznego postępu" (61).

Generowanie sztucznych czy irracjonalnych potrzeb skłania do marnotrawienia dóbr i środków potrzebnych do codziennej egzystencji lub rzeczywistego rozwoju. Polskie społeczeństwo nie należy do bogatych - jest ciągle na dorobku. Wedle najnowszych danych opublikowanych przez „Rzeczpospolitą” aż trzy miliony naszych rodaków dosłownie żyje w nędzy, rodziny mają coraz mniej środków finansowych do dyspozycji, a tnąc koszty życia, oszczędzają najpierw na jedzeniư ${ }^{47}$. Dodać do tego trzeba wciąż niemałe

47 Por. http://beta.rp.pl/artykul/884974-Polacy-ubozeja--Juz-3-milionyzyja-w-nedzy.html (29.09.2015). 
bezrobocie, zwłaszcza wśród młodych, i wielki problem emigracji zarobkowej, w takim czy innym wymiarze znany chyba każdej rodzinie w Polsce. Wyjazdy za chlebem stwarzają wiele problemów małżeńsko-rodzinnych, pomnażają zastępy eurosierot, nierzadko skutkują rozpadem rodzin.

W kraju pogłębia się polaryzacja społeczeństwa na tych bardzo bogatych i biedną większość. Zarobki, a co za tym idzie stopa życiowa większości polskich rodzin nie są wysokie; odbija się to również na dzieciach - dość rzec, iż - wedle danych Polskiej Fundacji Pomocy Dzieciom „Maciuś” - 800 tys. dzieci w Polsce jest głodnych lub niedożywionych ${ }^{48}$. Wedle najnowszych danych GUS (z września 2015 roku) aż 31 proc. osób z trzymilionowej grupy dotkniętych skrajną nędzą stanowią dzieci i młodzież do 18. roku życia. Oznacza to, że milion polskich dzieci żyje w rodzinach, którym nie starcza na zaspokojenie podstawowych potrzeb biologicznych. W rodzinach wielodzietnych (z co najmniej trojgiem dzieci na utrzymaniu) dochód jest aż o 41,4 proc. poniżej średniej - co dziesiąte dziecko żyje tam w skrajnej nędzy ${ }^{49}$. Wobec takich realiów nietrudno sobie wyobrazić, że rozpasana reklama może przyczynić się do jeszcze większego zubożenia polskich rodzin.

Szeroko pojęte dobro osoby ludzkiej, społeczeństwa i rodziny (zwłaszcza dzieci i młodzieży) wymagałoby całkowitego zakazu reklamy używek takich jak alkohol i wyroby tytoniowe. Jako palący problem legislacyjno-formacyjny jawi się również kwestia reklamy medykamentów i innych środków (para)farmaceutycznych. Polska

48 Por. http://www.pfpd.org/?page_id=2 (22.09.2015).

49 Por. http://beta.rp.pl/artykul/884974-Polacy-ubozeja--Juz-3-milionyzyja-w-nedzy.html (29.09.2015). 
zajmuje szóste miejsce w Europie w spożyciu leków i suplementów diety. Jako społeczeństwo wypijamy całe rzeki syropów, pochłaniamy góry pigułek i kapsułek. Przykładowo roczna sprzedaż Rutinoscorbinu to aż 14 mln opakowań, czyli około 1,2 mld tabletek. Wartość polskiego rynku farmaceutycznego w roku 2014 wyniosła aż 27,3 mld zł. To o 3,3 mld zł więcej niż rok wcześniej. Samych leków bez recepty Polacy kupili $680 \mathrm{mln}$ opakowań, wydając na to 11,4 mld zł. Te w istocie zatrważające dane to przede wszystkim skutek natarczywej reklamy. Koncerny farmaceutyczne wydają na reklamę więcej niż banki czy firmy teleinformatyczne. W roku 2014 było to rekordowe $871 \mathrm{mln}$ zł, czyli o 9 proc. więcej niż rok wcześniej ${ }^{50}$.

\section{Dziecięca bezbronność}

Jako że mężczyźni (partnerzy) bywają zwykle oporni na zakupy, gros reklam męskich produktów kierowanych jest do kobiet (partnerek). To niejako standardowy, w pewnym sensie „rodzinny” mechanizm reklamowy. Warianty tego zabiegu bywają różne, ale ich wspólnym mianownikiem jest przekaz: Kup swemu partnerowi to a to (np. kosiarkę, golarkę czy polisę), zadbaj o swego modnego mężczyznę, albo: należy ci się partner pachnący ekskluzywnym kosmetykiem.

Rodzice i wychowawcy szczególną troską powinni objąć dzieci, które konsumują reklamy tyleż chętnie, co bezwiedne. Są one najmniej krytycznymi odbiorcami reklam, czyli najbardziej narażonymi na manipulacje i wszelkie powodowane przez nie negatywne skutki. Na sam dźwięk dżingla zapowiadającego spot reklamowy w telewizji

50 http://wyborcza.pl/1,76842,17513743,My__Polacy_lekomani__Rekordowe_wydatki_na_leki_grozne.html (22.09.2015). 
dzieci zwykle już biegną do odbiornika. Potop reklam zalewa właściwie wszystkie programy adresowane do najmłodszych. Kolorowy świat reklamy dziecko traktuje jak najdosłowniej, nie zdaje sobie sprawy, że to świat, który w rzeczywistości nie istnieje, że to swoista gra, w której chodzi po prostu o wydanie pieniędzy.

Jak wspomnieliśmy, w reklamach produktów dla mężczyzn bezpośrednimi adresatkami spotu często bywają kobiety, które mają wyręczyć panów w zakupach; jeśli chodzi o reklamy produktów dziecięcych, konstruowane one są w ten sposób, aby dzieci - owładnięte reklamą - wymuszały na rodzicach zakupy. Reklama spełnia swe zadanie. Badania wykazują, że 90 proc. dzieci w wieku szkolnym prosi o zabawki lub produkty żywnościowe, których reklamy oglądały w telewizji. Ponadto prawie dwie trzecie matek podaje, iż słyszą, jak ich dzieci śpiewają hity reklamowe, których nauczyły się z telewizora przeważnie w wieku trzech lat ${ }^{51}$.

\section{Medialne zadania rodziców}

Kościół w mass mediach widzi - jak to ujął Sobór Watykański II „podziwu godne wynalazki techniki, które geniusz ludzki z pomocą Bożą odkrył w rzeczach stworzonych"52. Byłoby więc czymś wysoce niewłaściwym patrzeć na telewizję, komputer czy gazetę jako na coś z gruntu złego, jakieś „siedlisko szatana”. Z etycznego punktu

51 Por. E. Aronson, Człowiek-istota społeczna, tłum. J. Radzicki, Warszawa 1998, s. 89.

52 Sobór Watykański II, Dekret o środkach społecznego przekazu [dalej: DSP], 1, [w:] Sobór Watykański II, Konstytucje. Dekrety. Deklaracje, Poznań 2002, s. $87-95$. 
widzenia mass media są „obojętne” - tzn. są tylko narzędziem, które może być przez człowieka źle lub dobrze użyte. W podejściu do mediów można by sformułować następującą generalną zasadę etyczną: wszystko, co nawet potencjalnie może umniejszyć człowieka (odbiorcę) w godności jego człowieczeństwa, a w przypadku ludzi wierzących w godności dziecka Bożego - powinno być odrzucone. W praktyce oznacza to roztropne, krytyczne i selektywne podejście do oferty medialnej $j^{53}$.

Z oczywistych względów rodzice są medialnymi przewodnikami swych dzieci; powinni wiedzieć, co oglądają, co czytają, po jakich stronach internetowych serfują dzieci. To głównie na rodzicach spoczywa zadanie edukacji medialnej dzieci oraz ich ochrony przed zagrożeniami, jakie mogą płynąć ze strony publikatorów. Przypominał o tym wyraźnie św. Jan Paweł II, patron rodzin, w Orędziu na Światowy Dzień Środków Społecznego Przekazu w 2004 roku: „Rodzice jako pierwsi i najważniejsi wychowawcy swoich dzieci są też dla nich pierwszym źródłem wiedzy o mediach. Ich zadaniem jest wpojenie potomstwu umiejętności korzystania z umiarem, krytycznie, czujnie i roztropnie z tych środków w rodzinnym domu [...]. Nawet małym dzieciom można przekazać istotne informacje na temat mediów: że są one tworzone przez ludzi, którym zależy na przekazywaniu pewnych treści; że treści te mają często zachęcać do określonych zachowań - do kupienia jakiegoś towaru albo do postępowania w sposób budzący zastrzeżenia - które nie leżą w rzeczywistym interesie dziecka i nie są zgodne z prawdą

53 Por. Z. Sareło, Media w stużbie osoby..., dz. cyt., s. 120-124; por. M. Iłowiecki, Pilnowanie strażników, dz. cyt., s. 167. 
moralną; że dzieci nie powinny bezkrytycznie przyjmować ani naśladować tego, co znajdują w mediach"54.

Nie można zapominać, że współcześnie media (przede wszystkim telewizja oraz tzw. nowe media, czyli internet i jemu pochodne) są swoistymi elektronicznymi wychowawcami, a czasem niańkami dzieci. Rodzice jako wychowawcy powinni najpierw sami korzystać z mediów w sposób mądry i roztropny, aby dawać swym latoroślom dobry przykład; powinni też rozmawiać z dziećmi o mediach, ucząc ich kontrolowania treści i jakości podsuwanej im oferty. W rodzinach wskazane byłoby wspólne planowanie programów, jakie w nadchodzącym tygodniu warto by obejrzeć.

\section{Rodzicielsko-obywatelska czujność}

Jedna z istotnych tez teologii mediów głosi, iź środki komunikowania powinny troszczyć się o rodzinę, pomagać w wychowaniu dzieci i formowaniu młodzieży oraz promować wartości rodzinne (por. SR 10)55. Kiedy więc programy, publikacje czy audycje niosą treści szkodliwe dla chrześcijańskiej rodziny lub obraźliwe dla wiary i obyczajów, rodzice - jako wierzący świadomi swych obywatelskich praw - powinni publicznie protestować. Wymaga to oczywiście cywilnej odwagi i obywatelskiego zaangażowania, budowanych na świadomości, że w ustroju demokratycznym rację ma większość,

54 Jan Paweł II, Media w rodzinie: ryzyko i bogactwo, 5 Orędzie na XXXVIII Światowy Dzień Środków Społecznego Przekazu 2004 r., www.opoka.org.pl/biblioteka/W/WP/jan_pawel_ii/przemowienia/massmedia_24012004.html (23.09.2015).

55 Por. K. Pokorna-Ignatowicz, Kościót w świecie mediów..., dz. cyt., s. 146. 
ale większość aktywna. Rodzice mają prawo wpływać na treści programów medialnych, zwłaszcza publikatorów publicznych, choćby dlatego, że są płatnikami abonamentu RTV.

Etyka odbiorców wymaga również pewnej ascezy względem medialnej oferty. Jak wielokrotnie wspominaliśmy, media, zwłaszcza telewizja, mają tendencję do zawłaszczenia i deformowania życia rodzinnego, wypierania przez wirtualną fikcję żywych kontaktów międzyludzkich, uzależniania swych odbiorców. Osoba ludzka nie może być niewolnikiem pilota. W trosce o zdrowie duchowe, higienę psychiczna, dla dobra bliskich (choćby po to, aby im poświęcić więcej czasu) wskazane byłoby urządzić w rodzinie dzień czy tydzień bez telewizora. Od 1996 roku z inicjatywy Ogólnopolskiej Rady Ruchów Katolickich w czasie oktawy wielkanocnej promuje się w Polsce tzw. Biały Tydzień bez telewizji, wideo, internetu, gier komputerowych. Pomysłodawcy projektu nawołują, aby w miarę możliwości abstynencję medialną rozciągnąć też na Wielki Tydzień, przygotowujący do świąt paschalnych.

Według rzeczników akcji taka dobrowolna rezygnacja z mediów ma na celu:

- odpoczynek oczu i niezaśmiecanie (niebrudzenie) duszy w świętym okresie oktawy wielkanocnej;

- zrobienie rachunku sumienia z roli mediów w życiu i pomoc w podjęciu decyzji o ograniczeniu czasu poświęconego telewizji;

- uczenie się korzystania z bogactwa programów telewizyjnych przez świadomy ich wybór;

- poświęcenie większej ilości czasu rodzinie i bliskim oraz zwiększenie aktywności fizycznej (np. spacer);

- ponowne odkrycie ciekawych i twórczych sposobów spędzania wolnego czasu bez włączania telewizora; 
- zastanowienie się: czy przypadkiem naszej kreatywności życiowej, zdolności tworzenia relacji rodzinnych i międzyludzkich, troski o zdrowie fizyczne i psychiczne, czasu poświęconego ludziom potrzebującym nie zastępujemy oglądaniem telewizji ${ }^{56}$.

\section{Promocja mediów konfesyjnych}

Kościół katolicki, który w mediach widzi godne podziwu wynalazki techniki, odkryte przez ludzki geniusz dzięki Bożej pomocy, uczy wiernych, że istnienie publikatorów powinno być sposobem wielbienia Stwórcy za ten dar. Podkreśla też, że przysługuje mu naturalne prawo do korzystania z mass mediów i posiadania środków komunikacji (por. DSP 3).

Publikatory o proweniencji konfesyjnej, chrześcijańskiej, chcą pokazywać to, co zwykle pomija tzw. medialny mainstream; promować lokalność jako atrakcyjną formę życia „tu i teraz”, uwypuklać aspekty pozytywne zwykłych zdarzeń, które nie są sensacjami w pojęciu wysokonakładowych publikatorów, a którymi przecież żyją miliony ludzi w powszednim życiu. Katolickie media starają się opisywać rzeczywistość językiem aksjologii chrześcijańskiej, służyć wzajemnej komunikacji i zbliżeniu ludzi, pamiętać o transcendentnym wymiarze osoby ludzkiej. Do istoty ich misji należy nie tylko informacja, ale formacja i ewangelizacja. Służą temu programy stricte religijne, ale też publicystyczne, a nawet twórcza rozrywka. Jednakże, aby ta misja mogła być jeszcze bardziej owocna, potrzebna jest współpraca ludzi wierzących, aktywnych, którzy odpowiedzialnie

56 Por. http://www.orrk.pl/biuletyn-orrk/583-numer-12-kwiecie-1997-r (23.09.2015). 
i świadomie przeżywają swoją wiarę i mają wpływ na kształtowanie innych. Niezastąpione są w tym rodziny, które formują przyszłych wiernych Kościoła i obywateli państwa.

Warto więc w katolickich rodzinach jak najobficiej korzystać z mediów konfesyjnych oraz podsuwać je innym, np. krewnym czy sąsiadom. Ludzie chętnie karmią się różnokolorową tabloidową papka, więc taka pożywniejsza i wartościowsza strawa z katolickiego publikatora byłaby najpierw czymś w rodzaju medialnego detoksu. Treści zamieszczane $\mathrm{w}$ konfesyjnych publikatorach mają z reguły trwalszy charakter aniżeli te budowane na doraźnej sensacji - katolickim czasopismem można się więc międzysąsiedzko wymieniać, czyli jedna rodzina nabywa $\mathrm{w}$ danym tygodniu gazetę, korzysta i przekazuje drugiej, a w następnym tygodniu role się odwracają.

Dobrze byłoby też, aby w rodzinnej modlitwie pojawiała się intencja obejmująca dziennikarzy i pracowników mediów - aby rzetelnie wypełniali swą misję dla dobra i rozwoju wszystkich. Dobrą okazją ku temu jest również Dzień Środków Społecznego Przekazu, obchodzony w Kościele w Polsce w każdą trzecią niedzielę września.

\section{Wychowanie do tele(prze) życia}

Podkreślmy na koniec raz jeszcze, iż wielka penetracja współczesnego świata i życia rodzinnego przez media jest szczególnie niebezpieczna dla młodych. Może ona skutkować niedorozwojem psychiczno-fizycznym, uzależnieniem od wirtualnej rzeczywistości, zaburzeniami w nawiązywaniu i rozwijaniu relacji międzyludzkich, brakiem umiejętności funkcjonowania w realnym społeczeństwie. Zagrożenie w Polsce jest tym większe, że - w przeciwieństwie do krajów Zachodu - praktycznie brak jest u nas w programach 
i placówkach edukacyjnych elementarnej wiedzy o mediach. Skoro istnieje jako przedmiot szkolny wiedza o społeczeństwie czy przysposobienie do życia w rodzinie, czym prędzej trzeba wprowadzić nauczanie o mediach i przysposobienie do życia w wirtualnym świe$\mathrm{cie}^{57}$. Jan Paweł II postulował: „Przede wszystkim potrzebna jest szeroko zakrojona działalność formacyjna, szerząca właściwą wiedzę o mediach i ucząca świadomego korzystania z nich. Wprowadzane przez media nowe języki przekazu modyfikują procesy uczenia się i zmieniają jakość relacji międzyludzkich, toteż brak należytej formacji może stworzyć niebezpieczeństwo, że zamiast służyć ludziom, będą one posługiwać się nimi i wywierać na nich przemożny wpływ. Dotyczy to zwłaszcza młodych, którzy w sposób naturalny okazują zainteresowanie nowościami technicznymi i właśnie dlatego tym bardziej potrzebują przygotowania do odpowiedzialnego i krytycznego korzystania z mediów" (SR 11).

Trudno przecenić znaczenie rodzin dla teraźniejszości i przyszłości świata, podobnie jak trudno przecenić znaczenie mediów w życiu współczesnych rodzin. Parafrazując myśl klasyka, można by nawet zaryzykować twierdzenie, iż takie będą rzeczypospolite, jaki dialog rodzin z mediami i mediów z rodzinami.

57 Por. Z. Sareło, Media w stużbie osoby..., dz. cyt., s. 118-120.

Andrzej Turek, Media $w$ rodzinie - rodzina $w$ mediach.Wzajemne relacje $w$ aspekcie etycznym, [w:] Rodzina między pracą a płacą. Refleksja nad społeczną myśla encykliki Laborem exercens Jana Pawła II, red. Robert Kantor, Marek Kluz, Józef Młyński, Kraków 2016, s. 213-249. 